\title{
MOULD CONTAMINATION OF READY-TO-EAT CEREAL-BASED FOODS RETAILED IN LESOTHO WITH SPECIAL REFERENCE TO TOXIGENIC ASPERGILLUS FLAVUS
}

\author{
Mohale $\mathrm{S}^{{ }^{*}}$ and J Allotey ${ }^{2}$
}

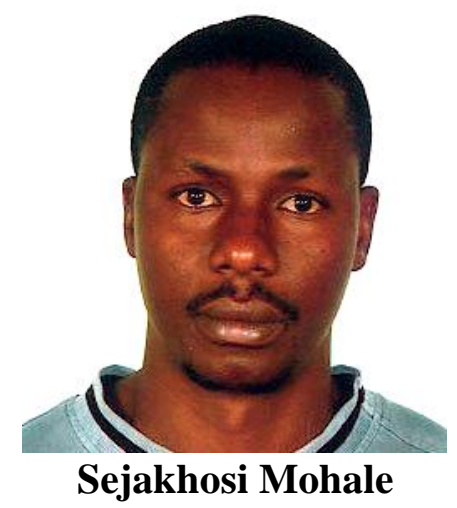

*Corresponding author email: sejakhosi@yahoo.co.uk

${ }^{1}$ National University of Lesotho, Faculty of Science and Technology Department of Biology, P O Roma 180, Lesotho.

${ }^{2}$ University of Botswana, Faculty of Science Department of Biological Sciences, Private Bag UB00704, Gaborone, Botswana. alloteyj@mopipi.ub.bw 


\section{ABSTRACT}

Samples belonging to four different brands (Instant Morvite ${ }^{\mathrm{TM}}$, E-Papa ${ }^{\mathrm{TM}}$, Ace Instant Porridge $^{\mathrm{TM}}$ and Roasted Morvite ${ }^{\mathrm{TM}}$ ) of ready-to-eat fortified cereal-based foodstuffs imported from the Republic of South Africa were bought from different retail outlets in the Roma valley, Lesotho and examined for contamination with moulds. All (100\%) of Roasted Morvite ${ }^{\mathrm{TM}}$ and E-Papa ${ }^{\mathrm{TM}}$ examined were contaminated with fungi. The greatest average fungal load $\left(1.33 \times 10^{5}\right)$ was recorded on Roasted Morvite ${ }^{\mathrm{TM}}$ samples. Although all the E-papa ${ }^{\mathrm{TM}}$ samples were contaminated, the upper limit average mould load $\left(1.0 \times 10^{4}\right)$ was the lowest compared to other brands that were analysed. A total of 226 isolates belonging to five different genera (Aspergillus, Penicillium, Cladosporium, Wallemia and unidentified genus) were recovered. For each of the brands assessed, average mould counts for some samples were above maximum permissible limits $\left(10^{3} \mathrm{CFU} / \mathrm{g}\right)$ established by World Food Programme guidelines for fortified blended foods. Aspergillus and Penicillium isolates exhibited greatest fungal population densities, 52.7\%, 36.3\%, respectively. Wallemia was the least frequently isolated genus in this study; only four isolates $(1.8 \%)$ recovered from all the samples investigated belonged to this genus. Of the Aspergillus species isolated, A. niger had the greatest relative density (39.5\%) followed by A. flavus (37.8\%), while Aspergillus amstelodami and unidentified Aspergillus species had the lowest. Of the 22 A. flavus isolates tested for sclerotia production potential, 18 produced large sclerotia with average diameter $>400.02 \pm 82.61$ on Czapek solution, agar. Ten (56\%) of these isolates were toxigenic as evidenced by formation of a blue fluorescence on the reverse of the plates when observed under UV (365 nm). It was concluded that the detection of above -permissible limits levels of moulds and aflatoxigenic fungi in some samples analysed presents a risk to consumers' health. It is, therefore, suggested that a statutory, independent and science-based body dedicated to protecting public health and consumer interest in the area of food safety and hygiene be established. The main function of such a body would be to take all reasonable steps to ensure that food produced, distributed or marketed in Lesotho meets the highest standards of food safety and hygiene available.

Key words: RTE, Moulds, Sclerotia, Aspergillus flavus, Toxigenicity 


\section{LIST OF ABBREVIATIONS}

RTEs - Ready-to-eat foodstuffs

MEA - Malt extract agar

CYA - Czapek yeast extract agar

CY20S - Czapek yeast extract sucrose

YES - Yeast extract sucrose

RFPD - Relative fungal population density

CFU/g - Colony forming units/gram

RDA - Recommended Dietary Allowance

WFP - World Food Programme

RCC - Research and Conference Committee

NUL - National University of Lesotho 


\section{INTRODUCTION}

Ready-to-eat (RTE) fortified maize- and/or sorghum-based foodstuffs originally developed in South Africa as an easy to prepare and consume mid-shift nutrient supplement for miners have found a place on the supermarket shelves. They are fairly popular in the Roma Valley, Lesotho and are sold in retail outlets throughout the valley. They provide for consumption with little preparation. They are made from precooked or roasted, milled cereals (sorghum or maize) to which vitamins, flavourants, colourants, salt and sugar have been added. Their preparation requires the emptying of the contents of sachet into a container and adding hot or cold water or milk to make an instant porridge. They contribute enormously to the recommended dietary allowance (RDA) for minerals, proteins and vitamins. They are cheaper than their substitutes; for example, Instant Morvite ${ }^{\mathrm{TM}}$ sells in the supermarkets at a third the price of cornflakes. The RTEs, being products based on cereals such as pre-cooked or roasted maize and sorghum and thus having low moisture content, are a potential substrate for fungal development, caused by contamination occurring during processing, packaging, distribution and appropriate storage in retail outlets [1]. Fungi commonly associated with low moisture content foodstuffs include Aspergillus, Penicillium, Eurotium, Chrysosporium and Wallemia [2, 3, 4, 5, 6, 7, 8]. Their occurrence in foodstuffs brings about a decrease of the storage life of the product and represents a danger of occurrence of mycotoxins.

Among the most notorious mycotoxin producers are fungi belonging to the Aspergillus flavus group namely, A. flavus Link: Fr, A. parasiticus Speare and A. nomius Kurtzman, Horn \& Hesseltine [9]. Aspergillus flavus and A. parasiticus invade various agricultural commodities during maturation in the field or after harvest and contaminate them with aflatoxins. Ingestion of food contaminated with aflatoxins has been associated with incidences of cancer, in China [10]; Swaziland [11]; malnutrition in Benin and Togo [12], Egypt [13], Sudan [14] and Kenya [15,]; and suppression of the immune system [16] and death in Kenya [17].

Aflatoxin production by $A$. flavus has been correlated with sclerotial morphology [18, 19]. In fact, a gene called veA found in A. flavus is necessary for the production of aflatoxins $\mathrm{B}_{1}$ and $\mathrm{B}_{2}$ and sclerotia [20]. Aspergillus flavus strains are divided into those that produce large sclerotia (L-strains) (average diameter $>400 \mu \mathrm{m}$ ) and those that produce small sclerotia (S-strains) average diameter $<400 \mu \mathrm{m}$. The two strains produce aflatoxin $\mathrm{B}_{1}$ and $\mathrm{B}_{2}$ only. However, the $\mathrm{S}$ - strain, though not frequently isolated produces numerous sclerotia and is potent producer of aflatoxins $[18,19]$. Strains that do not produce sclerotia are significantly less likely to produce aflatoxins than those that produce them [21].

The present research determined mould counts and mycoflora associated with imported cereal based RTEs with specific reference to aflatoxigenic A. flavus. The ultimate goal is to inform policy with regard to the need for establishment of infrastructure for constant inspection and monitoring of locally produced and imported foodstuffs in Lesotho to safeguard the health of humans. 


\section{MATERIALS AND METHODS}

\section{Source of Samples}

Forty five (45) samples of four different brands of fortified maize and/or sorghumbased foodstuffs imported into Lesotho (Table 1) were randomly purchased from retail outlets around the Roma valley between August 2009 and January 2010. The samples were, in their intact factory packing material, placed in brown paper bags and kept at $4^{\circ} \mathrm{C}$ until analysis.

\section{Determination of Moisture Content}

For each sample collected, thirty (30) grams was weighed and the mass recorded as "wet weight of sample." The sample was dried in an oven at $110^{\circ} \mathrm{C}$ for 24 hours. Thereafter, the sample was left to cool in a desiccator and then reweighed [8]. The mass was recorded as "dry weight of sample." Percentage moisture content was calculated using the equation below:

Where:

$$
\% \mathrm{~W}=[(\mathrm{A}-\mathrm{B}) / \mathrm{B}] * 100
$$

$\% \mathrm{~W}=$ percentage of moisture in the sample,

A = weight of wet sample (grams), and

$\mathrm{B}=$ weight of dry sample (grams)

\section{Enumeration and Identification of Fungal Isolates}

Samples (10 g) were added to $0.1 \%$ peptone water (CM0009, Oxoid LTD, Basingstoke, UK) (90 ml) and homogenized for 2 minutes in a blender (Waring Products, Torrington, USA). Three-stage 1:10 serial dilution of each sample was carried out using $0.1 \%$ sterile peptone water as the diluent. Aliquot $(0.1 \mathrm{ml})$ from the third dilution $\left(10^{-3}\right)$ for each sample were spread plated on Dichloran $18 \%$ Glycerol (DG18) (CM0729, Oxoid LTD, Basingstoke, UK) and the plates were incubated at $25^{\circ} \mathrm{C}$ for seven days. The colonies growing on the plates were counted and their number was expressed as colony forming units per gram sample (CFU/g sample).

Spore suspensions of all colonies growing from (DG18) were prepared and with the aid of a loop centrally inoculated on Malt Extract agar (MEA) (CM59; Oxoid LTD, Bakingstoke, UK) and then incubated at $25^{\circ} \mathrm{C}$ for seven days. Subsequently, the cultures were subjected to microscopic examination and with the help of standards texts such as Samson and van Reenen-Hoekstra [22] and Watanabe [23] were identified to genus level. For the identification of Aspergillus isolates to species level, three point inoculation technique was performed on three differential media; MEA, Czapek yeast extract agar (CYA), and Czapek Yeast Extract agar supplemented with $20 \%$ sucrose (CY20S) all prepared according to the recipes described by Klich and Pitt [24].

Additionally, slide cultures using agar plugs from the three media described above were prepared to avoid disturbing sporing structures upon removal and subsequent transfer to the microscope slides [25]. The media and incubation conditions used for 


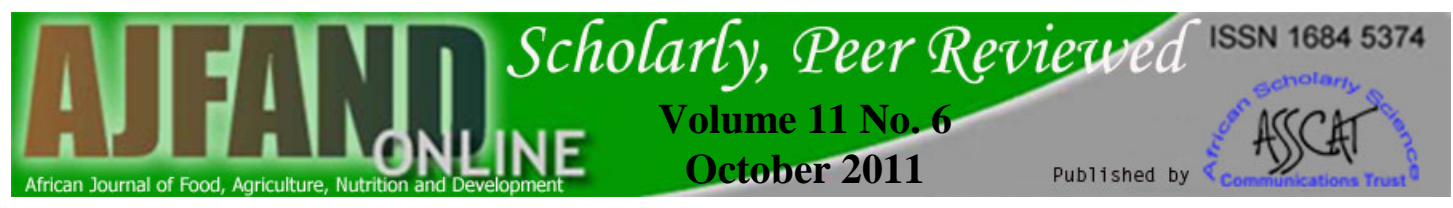

both slide cultures and plate cultures; were CYA, with incubation at $25^{\circ} \mathrm{C}$ and $37^{\circ} \mathrm{C}$; MEA and CY20S, incubated at $25^{\circ} \mathrm{C}$.

After seven-day incubation Aspergillus cultures were studied, the major and remarkable macroscopic features in species identification were the colony diameter, colour (conidia and reverse), presence of exudates and soluble pigment from plate cultures. Microscopic characteristic were examined from the slide cultures. These included the length of stipes, vesicle diameter and shape, conidia size, shape and roughness. Measurements were done with the help of Axiovert 135 microscope equipped with an AxioCam MRc camera and Axiovision 4.6 software (Carl Zeiss, Göttingen, Germany). Standard texts by Klich \& Pitt [24] and Samson \& van ReenenHoekstra [22] were used for identification. The relative density (RD) of fungal genera and Aspergillus species isolated were calculated according to Gonzalez et al. [6] as follows:

RFPD $(\%)=\{($ Number of isolates of a species or genus $) /$ Total number of fungi isolated $\} * 100$

\section{Estimation of Number and Size of Sclerotia Produced by Aspergillus flavus}

The method described by Cotty [18] was used to evaluate A. flavus isolates for ability to produce sclerotia. In brief, twenty-two (22) randomly selected single spore isolates of $A$. flavus were subcultured on $90 \mathrm{~mm}$ Czapek solution agar containing 3\% sucrose wt/v; $0.3 \% \mathrm{NaNO}_{3} \mathrm{wt} / \mathrm{v} ; 0.1 \% \mathrm{wt} / \mathrm{v} \mathrm{K}_{2} \mathrm{HPO}_{4} ; 0.05 \% \mathrm{MgSO}_{4} \cdot 7 \mathrm{H}_{2} \mathrm{O}$ wt/v; $\mathrm{KCl} ;$ $0.001 \% \mathrm{wt} / \mathrm{v} ; \mathrm{FeSO}_{4} \cdot 7 \mathrm{H}_{2} \mathrm{O} \mathrm{wt} / \mathrm{v}$, and $0.15 \% \mathrm{wt} / \mathrm{v}$ agar. The reverse of the plates was apportioned into eight equal sectors labeled 1 up to 8 . The plates were incubated at $30^{\circ} \mathrm{C}$ for 10 days in the dark.

A randomly selected sector of the colony was cut and conidia washed away with $70 \%$ alcohol. The sclerotia were then dislodged with a spatula and stuck on microscope slides and then counted. This procedure reduced human exposure to conidia [18]. To estimate the number of the sclerotia per culture plate, the counted number of sclerotia of the sector was multiplied by the total number of sectors (8) for each plate. The diameters of the sclerotia were measured with the help of Axiovert 135 microscope equipped with an AxioCam MRc camera and Axiovision 4.6 software (Carl Zeiss, Göttingen, Germany) on the assumption that the sclerotia were spherical.

\section{Screening Aspergillus flavus isolates for Aflatoxin Production}

Eighteen (18) single spore isolates of A. flavus that produced sclerotia were screened for ability to produce aflatoxins. Spores from 7-day old growing cultures grown at $25^{\circ} \mathrm{C}$ of all the single spore 18 isolates were suspended in sterile media consisting of $0.2 \%$ technical agar: $(\mathrm{w} / \mathrm{v})$ and $0.025 \%$ Tween $80:(\mathrm{w} / \mathrm{v})$. This was done so as to prevent formation of stray colonies on plates. The prepared spore suspensions were subsequently centrally inoculated with a loop on plates containing 50\% Coconut Cream agar (CCA) supplemented with $0.05 \%$ chloramphenicol. Three CCA plates per strain were inoculated. The plates were incubated at $25^{\circ} \mathrm{C}$ in the dark for 10 days after which the reverse of the plates was observed under UV light (365 nm) for formation of blue fluorescence indicative of ability to produce aflatoxins [26]. 


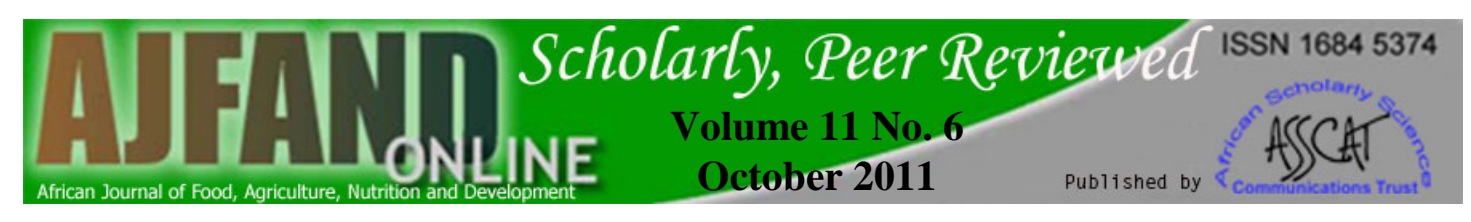

\section{RESULTS}

\section{Moisture Content of RTE Cereal Based Foods.}

The moisture content of the samples of ready-to-eat cereal based food products tested varied widely with means ranging from of 2.5\% (Roasted Morvite) to $8.08 \%$ (Instant morvite) (Figure 1).

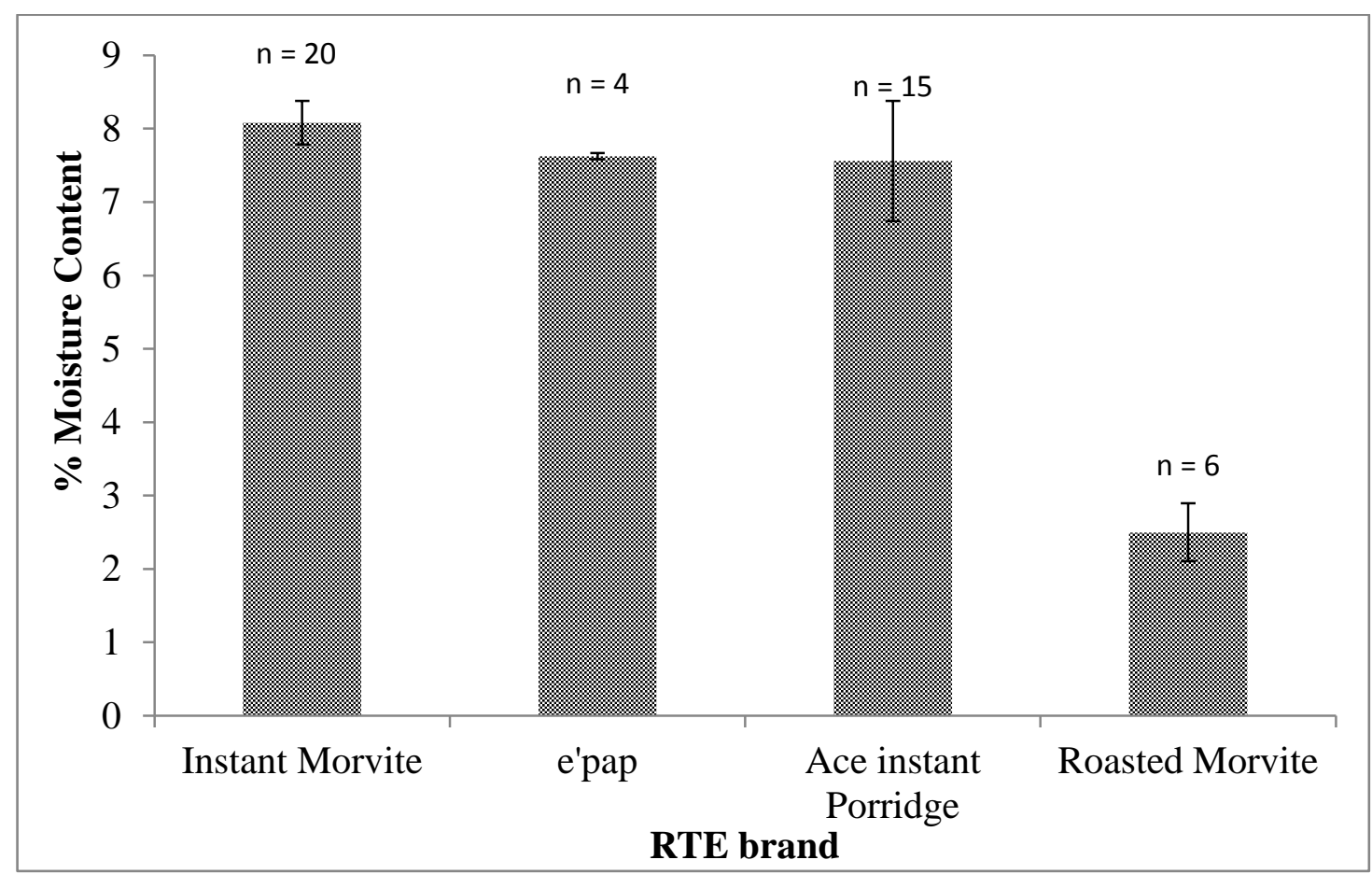

Figure 1: Percentage moisture content of the different samples analysed; twodirectional bars represent \pm SD.

\section{Mould Count of the RTE Brands}

All (100\%) E-papa ${ }^{\mathrm{TM}}$ and Roasted morvite ${ }^{\mathrm{TM}}$ samples were contaminated with fungi. Thirteen (65\%) of Instant Morvite ${ }^{\mathrm{TM}}$ samples were contaminated with fungi. Greatest fungal load was observed on Roasted Morvite ${ }^{\mathrm{TM}}$ samples with average mould load range of $2.0 \times 10^{4}-1.33 \times 10^{5} \mathrm{CFU} / \mathrm{g}$ (Table 2).

\section{Relative Densities of Fungal Genera in the RTE Brands}

A total of 226 fungal isolates were obtained from all the 34 contaminated samples of four different brands of ready- to- eat cereal based food products. One hundred and nineteen (52.7\%) (119) and 82 (36.3\%) of the isolates belonged to the genera Aspergillus and Penicillium, respectively (Table 3). Only 4 (1.8\%) isolates of Wallemia were recovered and these came from Instant Morvite ${ }^{\mathrm{TM}}$ only. On the other hand, only one genus (Aspergillus) was detected E-papa ${ }^{\mathrm{TM}}$ samples. 


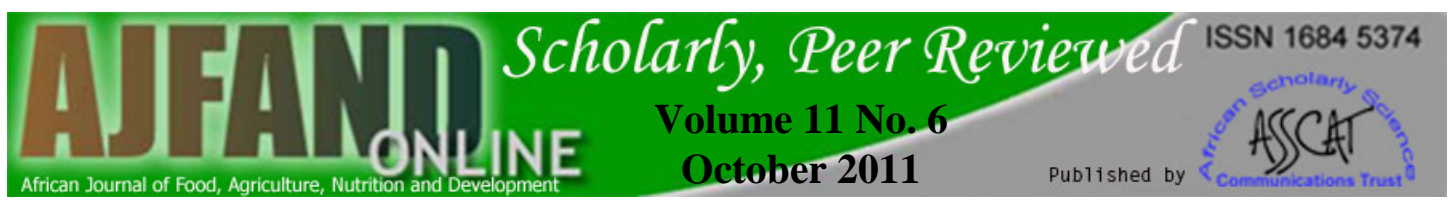

\section{Relative Density of Aspergillus species in the RTE Brands}

Of the 119 Aspergillus isolates recovered from the RTE brands, A. niger was the most predominant (39.5\%) followed by A. flavus (37.8\%) (Table 4). Aspergillus amstelodami and unidentified species had the lowest fungal population density (1.7\%). Additionally, A. flavus was isolated from all 4 different brands with greatest percentage relative density in Ace Instant Porridge ${ }^{\mathrm{TM}}$ and E-papa ${ }^{\mathrm{TM}} ; 59.1 \%$ and 33.3\% respectively, (Table 4 ).

Screening of A. flavus Isolates for Ability to Produce Sclerotia and Aflatoxins in

\section{Culture}

Of the 22 isolates screened for ability to produce sclerotia, 18 produced large sclerotia, with average diameter ranging between approximately $400 \mu \mathrm{m}$ and a high of $663 \mu \mathrm{m}$ (Table 5). Only 10 isolates out of 18 screened for ability to produce aflatoxins were toxigenic in culture (Table 5) as evidenced by blue fluorescence on the reverse of the plate when viewed under UV (365 nm, Figure 2). At least one isolated from any of the four brands of RTE was tested positive for aflatoxin production.

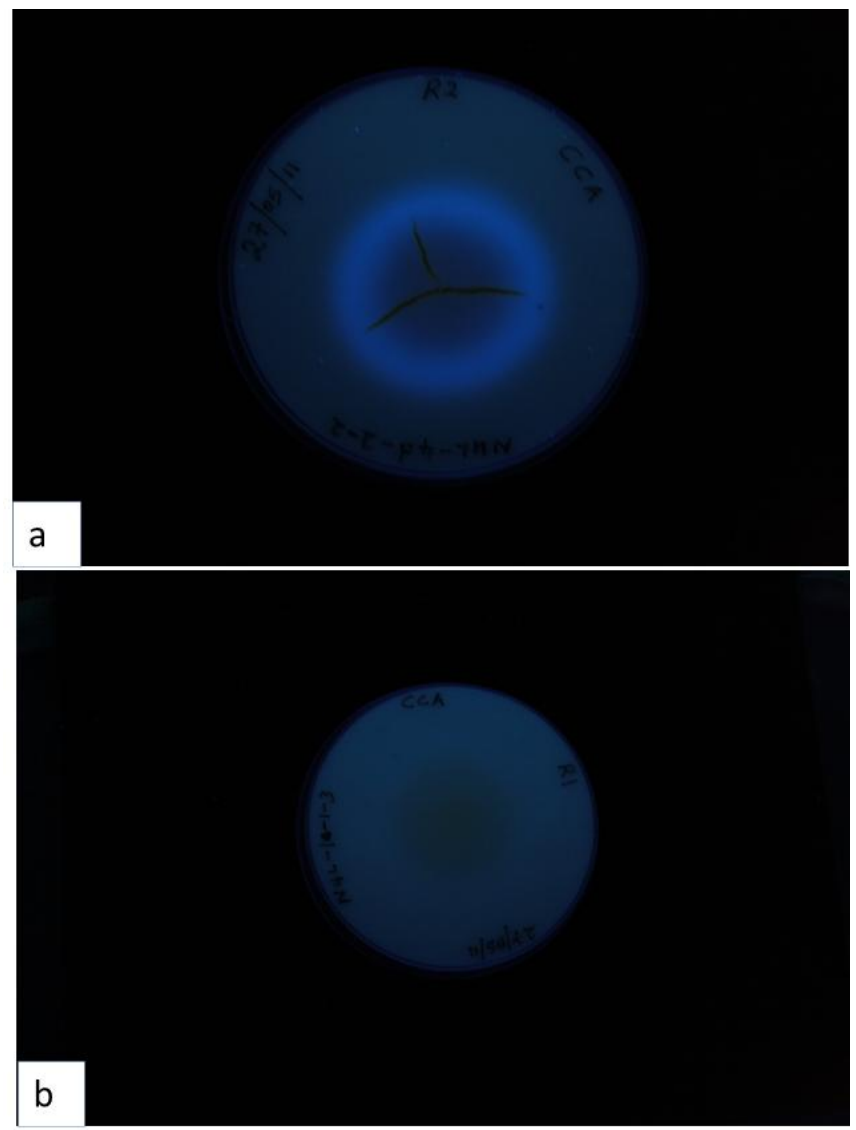

Figure 2: a) The reverse of CCA plate of toxigenic strain NUL-d4-2-2 showing blue fluorescence on the periphery of a colony when viewed under UV (365 $\mathrm{nm}$ ) after seven days of incubation.

b) Reverse of a non-toxigenic strain NUL-1a-1-3 under UV, no blue fluorescence observed. 


\section{DISCUSSION}

The average mould counts for some samples were above maximum permissible limits $\left(10^{3} \mathrm{CFU} / \mathrm{g}\right)$ established by World Food Programme (WFP) guidelines for fortified blended foods (Table 3). The moisture content values in the range $2.0-8.7 \%$ impose direct physiological stress resulting in accumulation of sugars (trehalose and glucose) and sugar alcohols (glycerol, erythritol and mannitol in fungal cells to reduce their internal water potential to avoid dehydration. Fungi that are able to withstand low moisture (decreasing water potential) conditions are xerotolerant and those that thrive under such conditions are xerophilic [27, 28].

Comparatively, Roasted Morvite ${ }^{\mathrm{TM}}$ exhibited greatest fungal load (CFU/g). This could be attributed to the process of manufacturing of this brand. Perhaps, this observation is in part attributable to the manufacturing process of Roasted Morvite ${ }^{\mathrm{TM}}$. Unlike the other brands, the major cereal ingredient in Roasted Morvite ${ }^{\mathrm{TM}}$, is cooked and later roasted downstream during processing. This repeated handling could increase the exposure of the product to more fungal spore inoculum, which would have been killed during the cooking process. Otherwise contamination could have occurred during the production process such as addition of other ingredients and during packaging.

In the present study, both xerotolerant Aspergillus and Penicillium spp. and xerophilic (Wallemia spp. and Aspergillus amstelodami) fungi were recovered from the samples analysed. Aspergillus and Penicillium spp. are common contaminants of maize and sorghum [3, 6, 7, 8]. The investigated RTE brands in this study are all products of sorghum and other ingredients except Ace Instant Porridge ${ }^{\mathrm{TM}}$, which does not contain sorghum at all (Table 1). These results are in agreement with reports by other researchers [5]. The predominance of both Aspergillus and Penicillium species found in this study concurs with published evaluation of post-harvest maize in Argentina and Nigeria for contamination with mycoflora [6, 7, 29] and sorghum in Thailand and Brazil [2, 4]. Aspergillus, Cladosporium and Penicillium, were the most common genera recovered from the cereal-based baby food samples imported into Uganda [8]. Wallemia spp. was recovered from some of the samples assessed. Vytrasová et al. [5] isolated Wallemia sebi and Aspergillus amstelodami from bakery products with similar moisture contents to the products investigated in this study. Cladosporium together with Penicillium and Aspergillus are associated with maize during storage [7]. Thus, the findings of the study are in conformity with the work that has been reported elsewhere [8]. In Uganda, Ismail et al. [8] reported isolation frequencies of $72 \%$ and $50 \%$ for Cladosporium spp. and Penicillium respectively in imported cereal based baby foods.

Ten out of the 18 (56\%) A. flavus isolates tested for ability to produce aflatoxins on $50 \%$ CCA were toxigenic as evidenced by formation of a blue fluorescence (Figure 2) [26]. Formation of large sclerotia (average diameter $>400 \mu \mathrm{m}$ ) on Czapek solution agar by $A$. flavus isolates has been associated with ability to produce B-aflatoxin [18, 19]. There was no attempt to quantify aflatoxins from the RTEs; however, the recovery of aflatoxigenic $A$. flavus from the brands is an indicator of the possibility that the brands could be contaminated with aflatoxins.

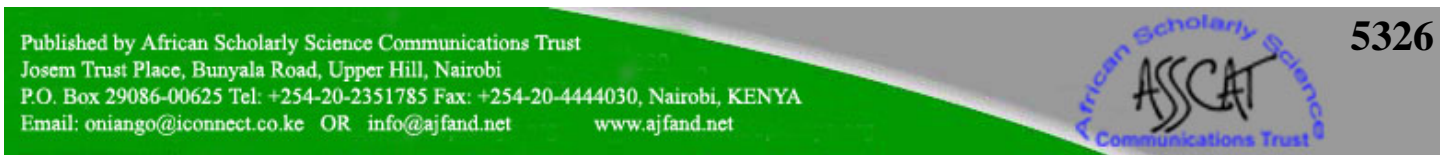




\section{CONCLUSION}

It was concluded that the detection of relatively high levels of moulds and aflatoxigenic fungi in some samples analysed presents a risk to consumers' health. It is, therefore, suggested that a statutory, independent and science-based body dedicated to protecting public health and consumer interest in the area of food safety and hygiene be established. Its main function would be to take all reasonable steps to ensure that food distributed or marketed in Lesotho meets the highest standards of food safety and hygiene available. Presently, such a body is non-existent in Lesotho.

\section{ACKNOWLEDGEMENT}

This work was conducted with a grant provided by the Faculty of Science and Technology, Research and Conference Committee (RCC), National University of Lesotho (NUL). Our sincere gratitude also goes to them and to Dr 'Mapotso Kena from the Faculty of Agriculture, University of Lesotho for her assistance in the identification of some of the isolates. 


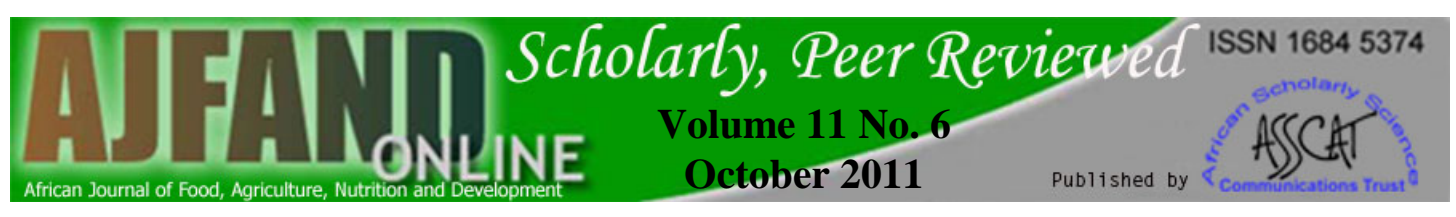

Table 1: RTE Brands Analysed

\begin{tabular}{|c|c|c|c|}
\hline RTE Brand & Main components & $\begin{array}{c}\text { Country of } \\
\text { Origin }\end{array}$ & Manufacturer \\
\hline Instant Morvite $^{\mathrm{TM}}$ & $\begin{array}{l}\text { Pre-cooked sorghum, sugar, } \\
\text { citric acid, minerals, salt, } \\
\text { sweetener }\end{array}$ & RSA & King Food \\
\hline $\begin{array}{l}\text { Ace Instant } \\
\text { Porridge }^{\mathrm{TM}}\end{array}$ & $\begin{array}{l}\text { Pre-cooked maize meal, cane } \\
\text { sugar, salt, vitamins, } \\
\text { flavourants, and colorant. }\end{array}$ & RSA & King Food \\
\hline E-papa TM & $\begin{array}{l}\text { Pre-cooked maize, soy, } \\
\text { sorghum, sugar, salt, probiotics, } \\
\text { flavourants, antioxidants, } \\
\text { vitamins. }\end{array}$ & RSA & Econocom Foods \\
\hline Roasted Morvite $^{\mathrm{TM}}$ & $\begin{array}{l}\text { Pre-cooked sorghum, sugar, } \\
\text { minerals, salt, sweetener }\end{array}$ & RSA & King food \\
\hline
\end{tabular}




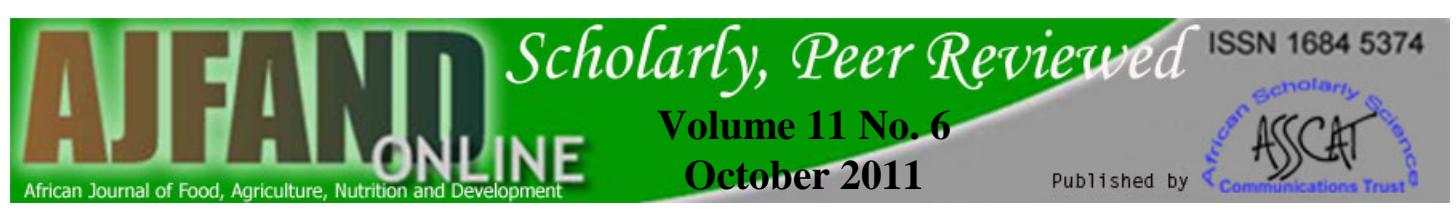

Table 2: Mould Count in RTE Foods

\begin{tabular}{lccc}
\hline RTE Brand & $\begin{array}{c}\text { Total number of } \\
\text { analysed } \\
\text { samples } \\
\mathbf{N = 4 5}\end{array}$ & $\begin{array}{c}\text { No. of samples } \\
\text { contaminated with } \\
\text { fungi (\%) }\end{array}$ & $\begin{array}{c}\text { Range average colony } \\
\text { forming units (CFU/g of } \\
\text { sample) }\end{array}$ \\
\hline Instant Morvite & 20 & $13(65)$ & $0-3.7 \times 10^{4}$ \\
E-Papa & 4 & $4(100)$ & $3.3 \times 10^{3}-1.0 \times 10^{4}$ \\
$\begin{array}{l}\text { Ace Instant } \\
\text { Porridge }\end{array}$ & 15 & $11(73)$ & $0-2.3 \times 10^{4}$ \\
Roasted Morvite & 6 & $6(100)$ & $2.0 \times 10^{4}-1.33 \times 10^{5}$ \\
Total & 45 & $34(75.6)$ & \\
\hline
\end{tabular}

Table 3: Relative Densities (RD) of Different Genera of Fungi Isolated from RTE Brands Based upon Total Number of Isolates $(n=226)$

\begin{tabular}{|c|c|c|c|c|c|c|c|c|c|c|}
\hline \multirow[t]{2}{*}{ Mould genera } & \multicolumn{2}{|c|}{$\begin{array}{c}\text { *Instant } \text { Inte } \\
\text { Morvite }^{\mathrm{TM}}\end{array}$} & \multicolumn{2}{|c|}{ E-Papa $^{\mathrm{TM}}$} & \multicolumn{2}{|c|}{$\begin{array}{l}\text { Ace Instant } \\
\text { Porridge }^{\mathrm{TM}}\end{array}$} & \multicolumn{2}{|c|}{$\begin{array}{c}\text { Roasted } \\
\text { Morvite }^{\mathrm{TM}}\end{array}$} & \multicolumn{2}{|c|}{ Total } \\
\hline & $\begin{array}{c}\text { No. } \\
\text { Isolates }\end{array}$ & $\begin{array}{l}\mathrm{RD} \\
(\%)\end{array}$ & $\begin{array}{c}\text { No. } \\
\text { Isolates }\end{array}$ & $\begin{array}{l}\mathrm{RD} \\
(\%)\end{array}$ & $\begin{array}{c}\text { No. } \\
\text { Isolates }\end{array}$ & $\begin{array}{l}\mathrm{RD} \\
(\%)\end{array}$ & $\begin{array}{c}\text { No. } \\
\text { Isolates }\end{array}$ & $\begin{array}{l}\mathrm{RD} \\
(\%)\end{array}$ & $\begin{array}{c}\text { No. } \\
\text { Isolates }\end{array}$ & $\begin{array}{l}\mathrm{RD} \\
(\%)\end{array}$ \\
\hline Aspergillus & 23 & 53.5 & 6 & 100 & 22 & 73.3 & 68 & 44.4 & 119 & 52.7 \\
\hline Penicillium & 16 & 37.2 & ND & - & 6 & 20.0 & 60 & 39.7 & 82 & 36.3 \\
\hline Cladosporium & ND & - & ND & - & 2 & 6.7 & 3 & 2.0 & 5 & 2.2 \\
\hline Wallemia & 4 & 9.3 & ND & - & ND & - & ND & - & 4 & 1.8 \\
\hline Unidentified & ND & - & ND & - & ND & - & 16 & 10.6 & 16 & 7.0 \\
\hline Total & 43 & 100 & 6 & 100 & 30 & 100 & 147 & 100 & 226 & 100 \\
\hline
\end{tabular}

*ND - Not Detected 


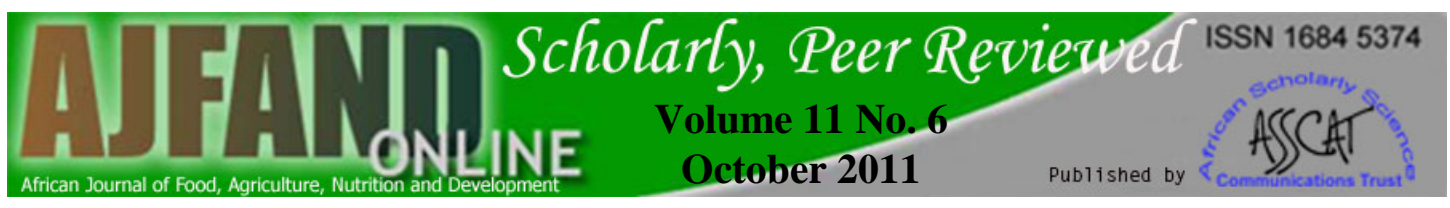

Table 4: Relative Density (\%) Based upon Aspergillus Isolates $(\mathrm{n}=119)$

\begin{tabular}{|c|c|c|c|c|c|c|c|c|c|c|}
\hline \multirow{2}{*}{$\begin{array}{l}\text { Species of } \\
\text { Aspergillus } \\
\text { genera }\end{array}$} & \multicolumn{2}{|c|}{$\begin{array}{c}\text { *Instant } \\
\text { Morvite }^{\mathrm{TM}}\end{array}$} & \multicolumn{2}{|c|}{ E-Papa ${ }^{\mathrm{TM}}$} & \multicolumn{2}{|c|}{$\begin{array}{l}\text { Ace Instant } \\
\text { PorridgeTM }^{\mathrm{TM}}\end{array}$} & \multicolumn{2}{|c|}{$\begin{array}{c}\text { Roasted } \\
\text { Morvite }^{\mathrm{TM}}\end{array}$} & \multicolumn{2}{|c|}{ Total } \\
\hline & $\begin{array}{c}\text { No. } \\
\text { Isolates }\end{array}$ & $\begin{array}{l}\mathrm{RD} \\
(\%)\end{array}$ & $\begin{array}{c}\text { No. } \\
\text { Isolates }\end{array}$ & $\begin{array}{l}\mathrm{RD} \\
(\%)\end{array}$ & $\begin{array}{c}\text { No. } \\
\text { Isolates }\end{array}$ & $\begin{array}{l}\mathrm{RD} \\
(\%)\end{array}$ & $\begin{array}{c}\text { No. } \\
\text { Isolates }\end{array}$ & $\begin{array}{l}\mathrm{RD} \\
(\%)\end{array}$ & $\begin{array}{c}\text { No. } \\
\text { Isolates }\end{array}$ & $\begin{array}{l}\mathrm{RD} \\
(\%)\end{array}$ \\
\hline flavus & 6 & 26.1 & 2 & 33.3 & 13 & 59.1 & 24 & 35.3 & 45 & 37.8 \\
\hline niger & 12 & 52.2 & 0 & 0 & 5 & 22.7 & 30 & 44.1 & 47 & 39.5 \\
\hline sojae & 4 & 17.4 & 4 & 66.7 & 3 & 13.6 & 12 & 17.6 & 23 & 19.3 \\
\hline amstelodami & ND & - & ND & - & 1 & 4.5 & 1 & 1.5 & 2 & 1.7 \\
\hline unidentified & 1 & 4.3 & ND & - & ND & - & 1 & 1.5 & 2 & 1.7 \\
\hline Total & 23 & 100 & 6 & 100 & 22 & 100 & 68 & 100 & 119 & 100 \\
\hline
\end{tabular}

* ND = Not Detected 


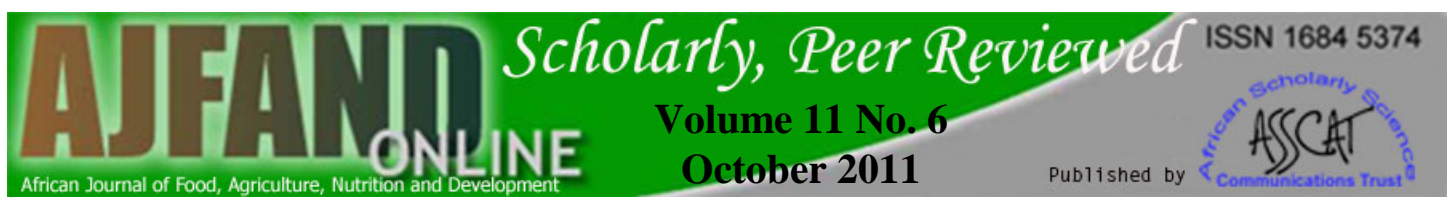

Table 5: Toxigenicity and Sclerotia Production by Aspergillus flavus Isolates

\begin{tabular}{|c|c|c|c|}
\hline Isolate ID & $\begin{array}{c}\text { Blue } \\
\text { fluorescence } \\
\text { under UV } \\
(365 \mathrm{~nm})\end{array}$ & $*$ Sclerotia diameter $(\mu \mathrm{m}) \pm \mathrm{SD}^{*}$ & No. of sclerotia per plate \\
\hline Nul 1s-2-1 & - & $452.62 \pm 83.44$ & 1104 \\
\hline Nul 4d-2-2 & + & $524.04 \pm 105.45$ & 552 \\
\hline Nul 4a-3-5 & - & $531.39 \pm 92.52$ & 600 \\
\hline Nul 3o-2-1 & + & $460.14 \pm 88.82$ & 1088 \\
\hline Nul 3n-2-1 & - & $468.19 \pm 89.60$ & 1200 \\
\hline Nul 3b-2-1 & + & $510.52 \pm 74.01$ & 624 \\
\hline Nul 3l-2-1 & - & $430.26 \pm 103.77$ & 328 \\
\hline Nul 3j-2-1 & - & $495.86 \pm 87.39$ & 304 \\
\hline Nul 4a-2-4 & + & $483.50 \pm 104.52$ & 256 \\
\hline Nul 3o-1-2 & + & $531.74 \pm 108.98$ & 552 \\
\hline Nul 1a-1-2 & + & $662.57 \pm 137.14$ & 384 \\
\hline Nul 4d-2-3 & + & $400.02 \pm 82.61$ & 856 \\
\hline Nul 1a-1-3 & - & $619.93 \pm 119.81$ & 688 \\
\hline Nul 2a-2-12 & + & $458.26 \pm 148.51$ & 88 \\
\hline Nul 3b-3-1 & - & $474.81 \pm 148.76$ & 344 \\
\hline Nul 3o-1-2 & + & $591.60 \pm 132.61$ & 248 \\
\hline Nul 3o-3-1 & + & $460.74 \pm 72.22$ & 552 \\
\hline Nul 3f-2-1 & - & $496.89 \pm 71.50$ & 520 \\
\hline
\end{tabular}

*Means based on 20 sclerotia chosen randomly, from each isolate plate 


\section{REFERENCES}

1. Osborne BG Mycotoxins and the Cereals Industry. J. Food Technol. 1982; 17: $1-9$.

2. Pitt JI, Bhudhasamai K, Miscamble BF, Wheeler KA and P Taboon-EK The normal mycoflora of commodities from Thailand: Beans, rice, small grains and other commodities. Int. J. Food Microbiol. 1994; 23: 35-53.

3. Pitt JI and AD Hocking Fungi and food spoilage. Blackie Academic and Professional, London. 1997.

4. da Silva JB, Pozzi CR, Mallozzi ABM, Ortega EM and B Corrêa Mycoflora and occurrence of aflatoxin $b_{1}$ and fumonisin $b_{1}$ during storage of Brazilian sorghum. J. Agric. Food Chem. 2000; 48: 4352-4356.

5. Vytřasová J, Přibáňová $\mathbf{P}$ and $\mathbf{L}$ Marvanová Occurrence of xerophilic fungi in bakery gingerbread production. Int. J. Food Microbiol. 2002; 72: 91-96.

6. Gonzalez HHL, Resnik SL, Boca RT and WFO Marasas Mycoflora of Argentinian corn harvested in the main production area in 1990. Mycopathologica 1995; 130: 29-36.

7. Atehnkeng J, Ojiambo PS, Donner M, Ikotun T, Sikora RA, Cotty PJ and R Bandyopadhyay Distribution and Toxigenicity of Aspergillus species isolated from maize kernels from three agro-ecological zones in Nigeria. Int. J. Food Microbiol. 2008; 122: 74-84.

8. Ismail MA, Taligoola HK and R Nakamya Mycobiota associated with baby food products imported into Uganda with special reference to aflatoxigenic Aspergilli and aflatoxins. Czech Mycol. 2008; 60: 75-89.

9. Kurtzman CP, Horn BW and CW Hesseltine Aspergillus nomius, a new aflatoxin-producing species related to Aspergillus flavus and Aspergillus tamarii. Antonie van Leeuwenhoek. 1987; 53: 147-158.

10. Yeh F-S, Mo C-C, Luo S, Tong MJ and BE Henderson Hepatitis B Virus, aflatoxins and hepatocellular carcinoma in Southern Guangxi, China. Cancer Res. 1989; 49: 2506-2509.

11. Peers FG, Gilman GA and CA Linsell Dietary aflatoxins and human liver cancer - A Study on Swaziland. Int. J. Cancer. 1976; 17: 167-171.

12. Gong YY, Cardwell K, Hounsa A, Egal S, Turner PC, Hall AJ and CP Wild Dietary aflatoxin exposure and impaired growth in young children from Benin and Togo: Cross Sectional Study. BMJ. 2002; 325: 20-21. 
13. Hatem NL, Hassab HM, Abd Al-Rahman EM, El-Deeb SA and RL ElSayed Ahmed Prevalence of Aflatoxins in Blood and Urine of Egyptian Infants with Protein-energy Malnutrition. Food Nutri. Bull. 2005; 26: 49-56.

14. Hendrickse RG, Coulter BS, Lamplugh SM, Macfarlane SB, Williams TE, Omer MIA and GI Suliman Aflatoxins and kwashiorkor: A study in Sudanese children. BMJ.1982; 285: 843-846.

15. de Vries HR, Lamplugh SM and RG Hendrickse Aflatoxins and kwashiorkor in Kenya: A hospital based study in a rural area of Kenya. Ann. Trop. Paediatr. 1987; 7: 249-251.

16. Raisuddin S, Singh KP, Zaidi SIA, Paul BN and PK Ray Immunosuppressive effects of aflatoxins in growing rats. Mycopathologia. 1993; 124: 189-194.

17. Centres for Disease Control and Prevention (CDC). Outbreak of aflatoxin poisoning in Eastern and Central Provinces, Kenya. MMWR Morb. Mortal. Wkly Rep. 2004; 53: 790-793.

18. Cotty PJ Virulence and cultural characteristics of two Aspergillus flavus strains pathogenic on cotton. Phytopathology. 1989; 79: 808-814.

19. Cotty PJ and KF Cardwell Divergence of West African and North American Communities of Aspergillus Section Flavi. Appl. Environ. Microbiol. 1999; 65: 2264-2266.

20. Duran RM, Cary JW and M Calvo Production of cyclopiozonic acid, aflatrem and aflatoxin by Aspergillus flavus is regulated by veA, a gene necessary for sclerotial formation. Appl. Microbiol. Biotechnol. 2007; 73: 1158-1168.

21. Abbas HK, Weaver MA, Zablotowiez RM, Horn BW and WT Shier Relationships between aflatoxin production and sclerotia formation among isolates of Aspergillus Section Flavi from the Mississippi Delta. European Journal of Plant Pathology. 2005; 112: 283-287.

22. Samson RA and ES van Reenen-Hoekstra Introduction to Food-borne Fungi. Centraalbureau voor Schimmelcultures, Baarn, Netherlands. 1988.

23. Watanabe T Pictorial atlas of soil and seed fungi: morphologies of cultured species CRS Press, Florida, USA. 2002.

24. Klich MA and JI Pitt Laboratory Guide to Common Aspergillus species and their teleomorphs. CSIRO Division of Food Research. North Ryde, Australia. 1988. 
25. Harris JL Modified method for fungal slide culture. J. Clin. Microbiol. 1986; 24: 460-461.

26. Sultan $\mathbf{Y}$ and $\mathbf{N}$ Magan Mycotoxigenic fungi from peanuts from different geographic regions of Egypt. Mycotoxin Research. 2010; 26: 133-140.

27. Ramos AJ, Magan $\mathbf{N}$ and $\mathbf{V}$ Sanchis Osmotic and matric potential effects on growth, sclerotia and partitioning of polyols and sugars in colonies and spores of Aspergillus ochraceus. Mycol. Res. 1999; 103: 141-147.

28. Schimel J, Balser TC and $M$ Wallenstein Microbial stress-response physiology and its implications for ecosystem function. Ecology. 2007; 88: 1386-1394.

29. Etcheverry M, Nesci A, Barros G, Torres A and S Chulze Occurrence of Aspergillus section Flavi and Aflatoxin $\mathrm{B}_{1}$ in corn genotypes and corn meal in Argentina. Mycopathologia. 1999; 48: 37-41. 